\title{
The Antibacterial Activity of Honey and Lemon Juice against Streptococcus pneumoniae and Streptococcus pyogenes Isolates from Respiratory Tract Infections
}

\author{
Mshelia BM*, Adeshina GO and Onaolapo JA \\ Department of Microbiology, Federal University Birnin Kebbi, Nigeria
}

Submission: June 10, 2017; Published: August 14, 2017

*Corresponding author: Mshelia BM, Department of Microbiology, Faculty of Science, Federal University Birnin Kebbi, Kebbi State, Nigeria, Tel: 234-7036546824; Email: bata.mari@fubk.edu.ng

\begin{abstract}
This study was aimed to determine the antibacterial activity of honey and/or lemon juice on strains of Streptococcus pneumoniae and Streptococcus pyogenes from respiratory tract infections. Clinical isolates were collected from Ahmadu Bello University Teaching Hospital (ABUTH), Zaria and Ahmadu Bello University Health Services (ABUHS) Samaru campus, Zaria. The isolates were characterized by standard microbiological procedures. Antibacterial activity of the honey and lemon juice, as well as that of some standard antibiotic formulations was assayed using agar well diffusion and broth dilution method. Minimum Inhibitory and Bactericidal Concentrations were carried out. Rate of kill was also carried out to determine the death/survival rate of the bacterial isolates after exposure to the agents. Noticeable variations in the antibacterial activity of the agents were observed. Thus, inhibition zones ( $\mathrm{mm}$ ) ranging from 10-22 (100\% Honey), 14-29 (100\% Lemon) and 2029 (Honey/Lemon juice mixture) were obtained. However, Minimum Inhibitory Concentrations $(\mu \mathrm{g} / \mathrm{ml})$ range between 1.95-125 (Ceftriaxone), 1.56-NI (Gentamicin), 31.5-NI (Amoxicillin-Clavulanic acid), 0.98-62.5 (Levofloxacin), 50.0-NI (Azithromycin), 20.0-75.0 (100\% v/v Honey), 22.5-47.5 (100\% v/v Lemon juice) and 17.5-25.0 (Honey/Lemon juice mixture). However, for the rate of kill, Honey/Lemon juice mixture, Lemon juice affected complete killing at 120mintues; While, Ceftriaxone, Levofloxacin and Honey produced complete killing at 1440minutes. Therefore, from the findings, honey/lemon juice mixture, Lemon juice, Levofloxacin, Ceftriaxone and Gentamicin had higher antibacterial activity than Azithromycin, Amoxicillin-Clavulanic acid and Honey. However, for the statistical analysis, at $\mathrm{p} \geq 0.05$, there is significant difference between honey/lemon juice mixture and honey. In conclusion, the bacterial isolates were more susceptible to honey/lemon juice mixture, lemon juice, Levofloxacin, Ceftriaxone and Gentamicin; but less susceptible to Azithromycin, Amoxicillin-Clavulanic acid and Honey. Excellent bactericidal activity was observed with honey/lemon juice mixture, lemon juice compared to the honey alone. The findings in this research therefore provides scientific basis to the use of honey and lemon juice as an alternative medicine by the populace in the treatment of respiratory tract infections.
\end{abstract}

Keywords: Honey; Lemon juice; Standard antibiotics; Antibacterial activity; Bactericidal; Susceptibility

\section{Introduction}

Honey is a sweet food made by bees using nectar from flowers. The variety produced by honey bees (the genus Apis) is the one most commonly referred to and is the type of honey collected by beekeepers and consumed by humans. The various species include; Apis andreniformis, Apis florea, Apis dorsata, Apis cerana, Apis koschevnikovi, Apis mellifera, Apis nigrocincta. Other species include; Stingless bees, sometimes called stingless honey bees or simply meliponines, are a large group of bees (approximately 500 species), comprising the tribe Meliponinior subtribe Meliponina according to other authors [1]. Most microorganisms do not grow in honey because of its low water activity of 0.6 [2]. Hydrogen peroxide (H2O2), methylglyoxal (MGO), bee defensin, $\mathrm{pH}$, osmotic effect as well as leptosin were known to be responsible for the antimicrobial effects of honey $[3,4]$. Lemon fruit is an inexpensive, easily available citrus fruit, popular for its culinary and medicinal uses. The Lemon fruit juice consists of about 5\% citric acid that gives a sour (tarty) taste to the lemon [5]. Lemon is an important medicinal plant of the family Rutaceae. It is a rich source of vitamin $\mathrm{C}$ and it is cultivated mainly for its alkaloids, which are having anticancer activities and the antibacterial potential in crude extracts of different parts (viz., leaves, stem, root and flower) of Lemon against clinically significant bacterial strains has been reported [6]. Citrus flavonoids have a large spectrum of biological activity including antibacterial, antifungal, antidiabetic, anticancer and antiviral activities [7]. There are different varieties of lemon. 
This include: Bush lemon tree, Eureka, Lisbon, Meyer, Ponderosa, and Variegated pink. However, the species used in this work was the Eureka species as identified in the Herbarium section of Biological Science, Ahmadu Bello University, Zaria. Eureka fruit has a markedly ribbed surface. The fruit color is yellow at maturity. It is a sour lemon variety and usually has fewer seeds [5]. The pulp of a Eureka lemon is greenish-yellow (Plate 1).

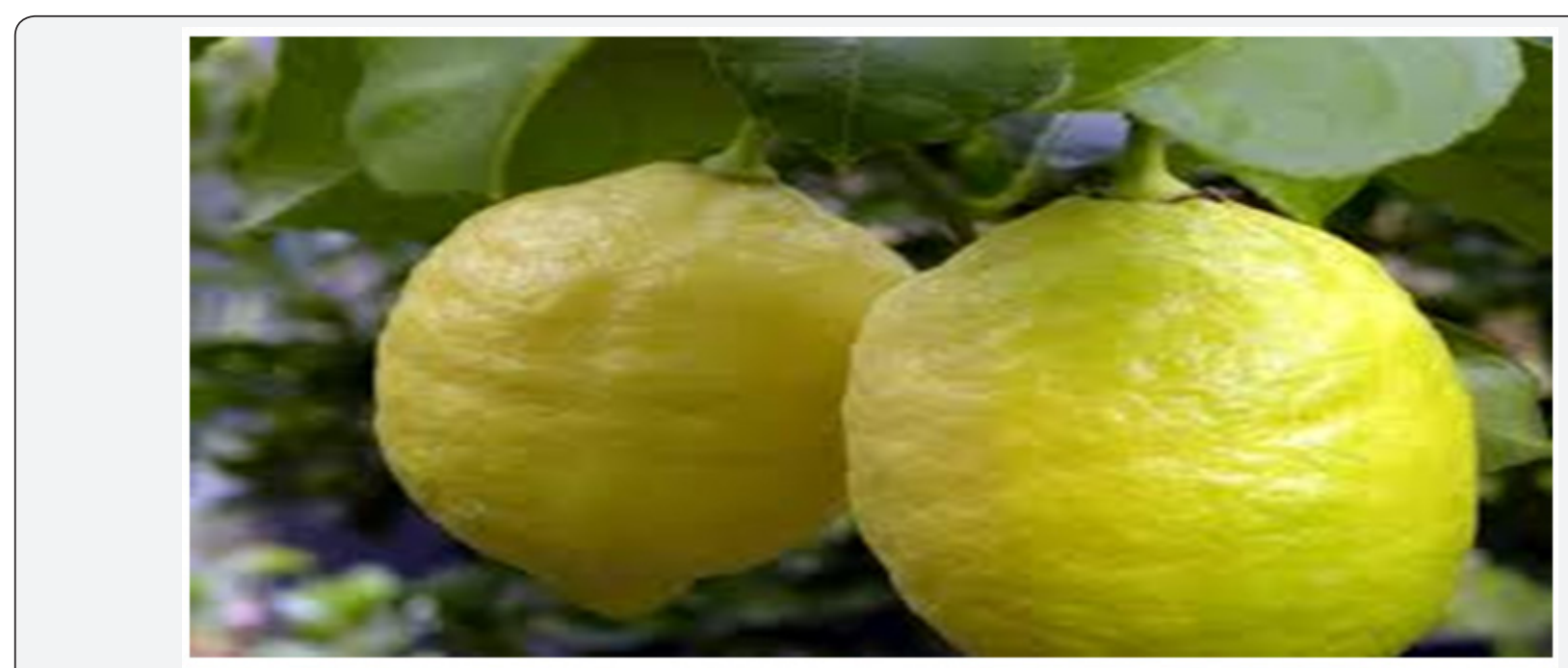

Plate I: Eureka Lemon Fruits (Moon Growers, 2010).

The respiratory tract is the part of the anatomy involved with the process of respiration [8]. The respiratory tract is divided into the upper and the lower respiratory tract. The upper respiratory tract is generally considered to be the airway above the glottis or vocal cords. This includes the nose, sinuses, pharynx, and larynx [9]. Whereas, the lower respiratory tract consists of the trachea (wind pipe), bronchial tubes, the bronchioles, and the lungs [10]. Infections involving this tract are referred to as respiratory tract infections [11]. Therefore, infection is the commonest and most serious complication of respiratory tract [8]. This includes pharyngitis, sometimes involving tonsillitis, and giving rise to a "sore throat", nasopharyngitis, otitis media, sinusitis, epiglottitis, bronchitis, pneumonia, etc. These results in significant morbidity, which may account for missed days of work and school, it also contributes to mortality. However, the fact that antimicrobials are being misused for treatment of cold, lemon and honey are considered natural soothers which have been utilized in some of these mild illnesses.

\section{Significance and Health Implication of the Test Organisms}

\section{Streptococcus pyogene}

Streptococcus pyogenes is the most common bacterial cause of sore throat [12]. A painful, red throat with white patches on your tonsils is characteristic of pharyngitis, otherwise known as strep throat. It is usually accompanied by swollen lymph nodes, fever, and headache. Occasionally it is also accompanied by nausea, vomiting, and abdominal pain [13].

Beta-hemolytic streptococci produce a toxin that forms a clear zone of hemolysis on blood agar, demonstrating its ability to destroy red blood cells [14]. This hemolysis is attributed to toxins formed by Group a streptococci called streptolysins.

It is estimated that there are more than 700 million infections (caused by Streptococcus pyogenes) worldwide each year and over 650,000 cases of severe, invasive infections that have a mortality rate of $25 \%$ [15]. Early recognition and treatment are critical; diagnostic failure can result in sepsis and death [16]. Diseases caused by Streptococcus pyogenes usually respond well to antibiotic treatment. The American Heart Association and the Infectious Diseases Society of America recommend penicillin as the drug of choice for treatment [17].

\section{Streptococcus pneumoniae}

Streptococcus pneumoniae, or pneumococcus, is a Grampositive, alpha-hemolytic, aerotolerant anaerobic member of the genus Streptococcus [18]. Despite the name, the organism causes many types of pneumococcal infections other than pneumonia. These invasive pneumococcal diseases include acute sinusitis, otitis media, meningitis, bacteremia, sepsis, osteomyelitis, septic arthritis, endocarditis, peritonitis, pericarditis, cellulitis, and brain abscess [19]. It is also one of the top two isolates found in ear infection, otitis media [20].

Worldwide in 2000, 14.5 million estimated episodes of invasive pneumococcal disease were reported in children younger than 5 years of age, which correlates to an estimated more than 800,000 deaths ( $11 \%$ of all deaths in this age group) [18].

\section{Materials and Methods}

\section{Methodology}

Study area: The study areas were Ahmadu Bello University Teaching Hospital (ABUTH) and Ahmadu Bello University 
Health Services (ABUHS) Zaria, Kaduna State, Nigeria. However, the research was conducted in the Faculty of Pharmaceutical Sciences, Department of Pharmaceutics and Pharmaceutical Microbiology, Ahmadu Bello University (ABU), Zaria, Nigeria.

Collection of materials and samples: Pure honey was collected from Taraba State, Nigeria. However, the lemon (Citrus limon, Eureka variety) was obtained from the Staff quarters in Area-A, ABU, Zaria.

Isolation and identification of bacteria from respiratory tract infections: Clinical isolates from sputum, throat, ear swab and nasal secretions samples were collected in ABUTH, Zaria and ABUHS, Samaru Campus, Zaria. These were then inoculated on Blood Agar, Chocolate agar, MacConkey agar and cetrimide agar, and the plates incubated at $370 \mathrm{C}$ for 24-48 hours. Identification of the growing microorganisms was done by colony morphology and Gram-Staining method. Pure colonies were sub-cultured on Blood agar, Nutrient agar and Chocolate agar media. Further identification or confirmation was carried out using Biochemical tests as recommended by [21].

Antibacterial activity testing: The honey was diluted with sterile distilled water to concentrations of between $25 \%(\mathrm{v} / \mathrm{v})$ to $50 \%(\mathrm{v} / \mathrm{v})$. The lemon was washed with water to remove sand and other particles and rinsed with sterile distilled water. It was cut with sterile knife before the juice was squeezed out and sieved. The sieving was done to remove the seeds and other particles. The juice was diluted with sterile distilled water to concentrations of between $25 \%(\mathrm{v} / \mathrm{v}$ ) to $50 \%(\mathrm{v} / \mathrm{v})$. However, for the combination studies, ratio of mixtures (Lemon juice: Honey: water) was as follows 10:50:40; 20:50:30; 30:50:20; 40:50:10; 50:50:0 (v/v) concentrations and Honey: Lemon juice: water at 10:50:40; 20:50:30; 30:50:20; 40:50:10; 50:50:0 (v/v) concentrations. Agar well diffusion technique as described by Adeniyi et al. [22] and Adeshina et al. [23] was used to determine the antibacterial activities of the Honey, Lemon juice and the combinations of the two agents. $20 \mathrm{mls}$ of Mueller Hinton agar were prepared and poured into sterile petri-dishes, and then allowed to set. Overnight culture of the test organism which was diluted in sterile normal saline to match 0.5 McFarland turbidity [24] was then spread thinly with sterile swab stick on the surface of the agar. Thereafter, holes were bored using sterile cork-borer (number 4) to make uniform wells on the inoculated agar. The bottom of the hole was then sealed with 2 drops of molten sterile Mueller Hinton agar and then filled with the test antibacterial agent (honey, lemon juice, honey/lemon juice). The standard antibiotic discs were placed at some points in the same Petri dishes with the test antibacterial agents (Honey and/or Lemon juice) for them to undergo the same conditions. Pre-incubation diffusion time (45 minutes to 1hour) was allowed, after which the petri-dishes were incubated at $37^{\circ} \mathrm{C}$ for $18-24 \mathrm{hrs}$. After the incubation period, the diameters of the zones of inhibition were measured in millimeters. Interpretation of zones sizes in terms of sensitivity or susceptibility, and resistance was based on the values provided by Clinical and Laboratory Standard Institute (CLSI) [25].

\section{Determination of Minimum Inhibitory Concentration (MIC) and Minimum Bactericidal \\ Concentration (MBC) of the agents}

The MIC was carried out using the broth dilution method as used by Kabir et al. [26] and as described by CLSI [25]. Stock solutions of $125 \mu \mathrm{g} / \mathrm{ml}$ were prepared for CRO, AMC, and LEV; $100 \mu \mathrm{g} / \mathrm{ml}$ and $50 \mu \mathrm{g} / \mathrm{ml}$ was also prepared for CN and AZM respectively based on their different MIC break point values. Two fold serial dilution of the stock solutions were made in eight (8) test tubes (plus three control test tubes; one containing Mueller Hinton broth and the test bacteria, another containing Mueller Hinton broth and the standard antibiotics and the other containing Mueller Hinton broth and Sterile distilled water) of Mueller Hinton broth, with the first test tube being a double strength and the others single strength to obtain concentrations between $125-0.98 \mu \mathrm{g} / \mathrm{ml}, 100-0.78 \mu \mathrm{g} / \mathrm{ml}$ and $50.0-0.39 \mu \mathrm{g} / \mathrm{ml}$. However, for the Honey and Lemon juice, $100 \mu \mathrm{g} / \mathrm{ml}, 90 \mu \mathrm{g} / \mathrm{ml}, 80 \mu \mathrm{g} / \mathrm{ml}, 70 \mu \mathrm{g} / \mathrm{ml}$ and $60 \mu \mathrm{g} / \mathrm{ml}$ of stock solutions were prepared. Two fold serial dilution of the stock solutions were also made (same procedure as above) to obtain concentrations between $100-0.78 \mu \mathrm{g} / \mathrm{ml}, 90.0-0.71 \mu \mathrm{g} / \mathrm{ml}, 80.0-$ $0.63 \mu \mathrm{g} / \mathrm{ml}, 70.0-0.55 \mu \mathrm{g} / \mathrm{ml}$ and $60.0-0.47 \mu \mathrm{g} / \mathrm{ml}$. The overnight cultures of the test bacterial isolates were diluted to match 0.5 McFarland turbidity. At this point, the organisms should be at a concentration of approximately $105 \mathrm{cfu} / \mathrm{ml}$. An aliquot of $100 \mu \mathrm{l}$ of the standardized inoculum was then inoculated to the different dilutions of the agents and the antibiotics in the 8 test tubes plus the organism-control test tube and incubated at 37 ${ }^{\circ} \mathrm{C}$ for 24 hours. The lowest concentration (highest dilution) of the honey and/or lemon or the antibiotics which showed clear solution or no visible bacterial growth (i.e. no turbidity) when compared with the control tubes, was regarded as the M.I.C.

However, M.B.C. was determined from the broth dilution tests, by sub-culturing to antibiotic free Mueller Hinton agar (i.e. Mueller Hinton Agar $+5 \%$ v/v tween 80 ) from tubes showing no visible growth after 24 hours incubation at $37^{\circ} \mathrm{C}$. The lowest concentration of an antibacterial agent that kills more than $99.9 \%$ of the initial inoculation after the 24hours incubation represents the MBC [27].

\section{Rate of kill}

Aliquot of $0.1 \mathrm{ml}$ of standardized overnight culture of the test organisms that were susceptible and those that were resistant to the standard antibiotics, honey, lemon juice and mixture of both (approximately $106 \mathrm{cfu} / \mathrm{ml}$ ) was added to $9.9 \mathrm{ml}$ each of test antibacterial agents (honey and/or lemon juice) formulated with sterile distilled water (using the concentrations of Sub-MIC, Around-MIC, and Above-MIC). This was mixed thoroughly and kept inside Digital shaker bath (Mc Donald Scientific International) at $37^{\circ} \mathrm{C}$. At different time interval $(0$, 
$30,60,120,240,360$ and 1440 minutes). $1 \mathrm{ml}$ test organism/ extract admixture was taken and ten-fold dilution protocol performed with sterile inactivated normal saline (i.e. normal saline with $5 \%(\mathrm{v} / \mathrm{v})$ Tween 80$)$. These dilutions were then plated out in duplicates on sterile molten Mueller-Hinton agar supplemented with $5 \%(\mathrm{v} / \mathrm{v})$ Tween 80 . The agar plates were then incubated at $37^{\circ} \mathrm{C}$ for 24 hours. After incubation, colonies observed were counted with the aid of a Colony Counter (NAPCO Model 630 Porland, Oregon, U. S. A.) [23,28]. These procedures were repeated for Sub-MIC, Around-MIC, and Above-MIC values of levofloxacin and ceftriaxone; as the standard antibacterial agents.

\section{Statistical analysis}

The zones of inhibitions obtained from the susceptibility tests carried out were expressed as Mean \pm Standard Error of Mean (SEM). The mean zone of inhibition of honey and lemon were also compared with that of the mixture and with that of the various antibiotics using Analysis of Variance (ANOVA) to determine the significant differences. Differences were considered significant if $\mathrm{P} \leq 0.05$ and not significant if $\mathrm{P} \geq 0.05$.

\section{Results and Discussion}

\section{Results}

Sample collection: A total of 126 Clinical isolates were collected from Sputum (83), Throat swab (26), Ear swab (14) and Nasal secretion (3) samples. The isolates identified and confirmed from these samples include 15 Klebsiella pneumoniae (26.8\%), 14 Staphylococcus aureus (25.0\%), 2 Haemophilus influenzae (3.57\%), 12 Pseudomonas aeruginosa (21.4\%), 7 Streptococcus pneumonia (12.5\%), 6 Streptococcus pyogenes $(10.7 \%)$. However, for the purpose of this research, more focus will be on Streptococcus pneumoniae and Streptococcus pyogenes.

Susceptibility pattern of the bacterial isolates to honey and lemon juice: Honey/lemon juice mixture, crude concentrations of honey and lemon juice gave wider zones of inhibition, while low zone of inhibition was seen with $25 \% \mathrm{v} / \mathrm{v}$ concentration of honey (Figure 1 \& 2).

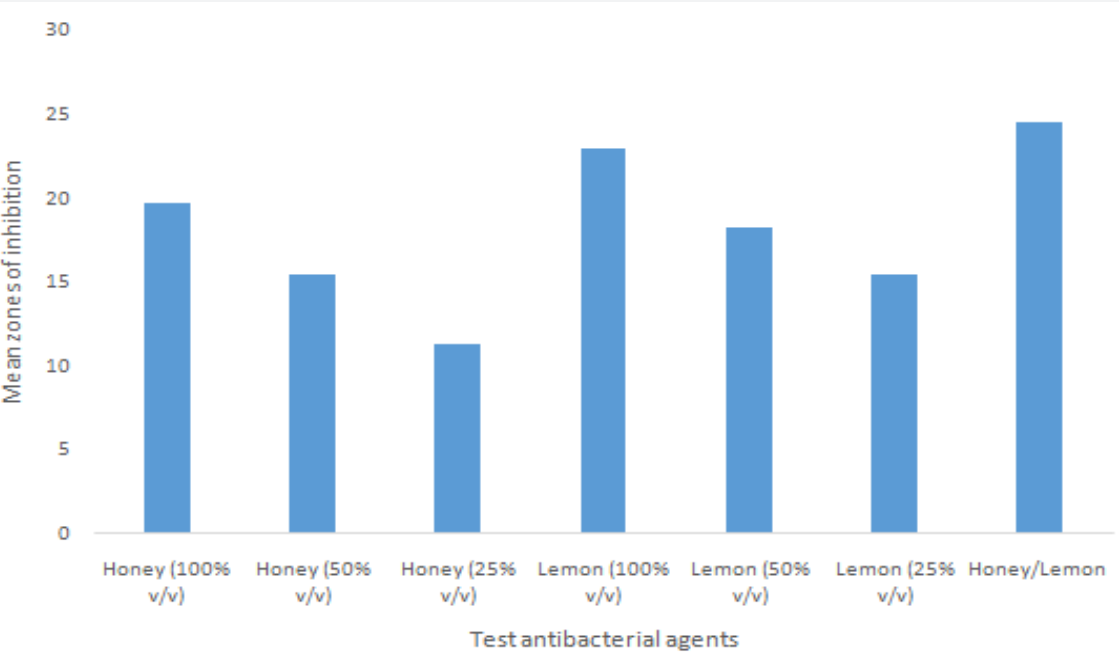

Figure 1: Susceptibility of Streptococcus pneumoniae to honey and lemon juice.

30
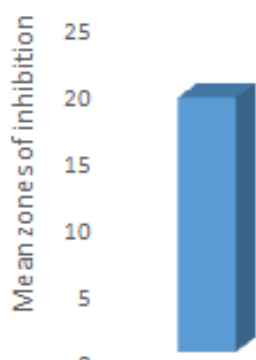
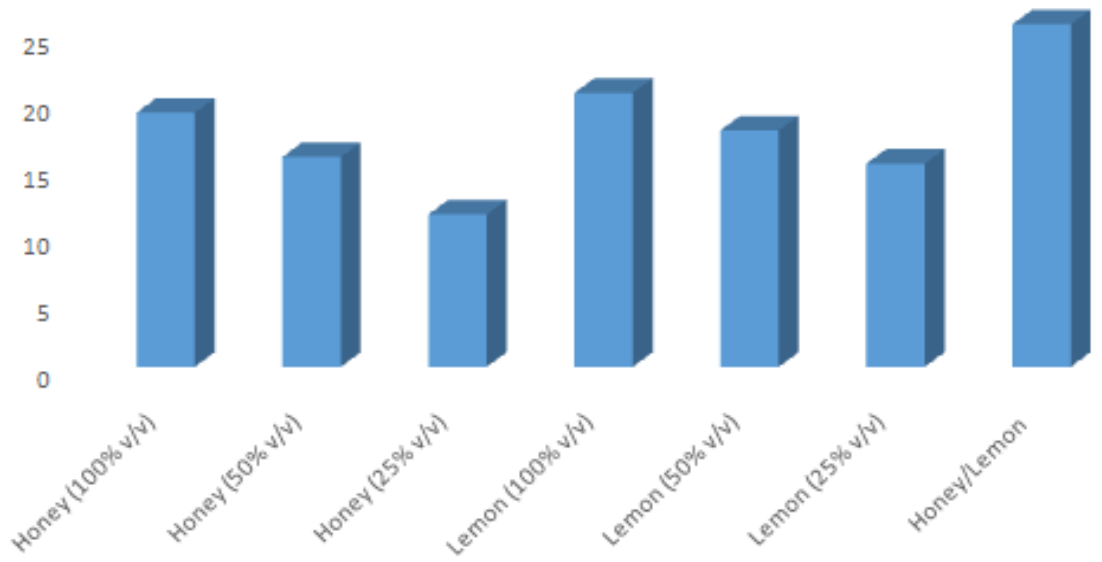

Test antibacterial agents

Figure 2: Susceptibility of Streptococcus pyogenes to honey and lemon juice. 
Comparing the Minimum Inhibitory Concentration (MIC) and Minimum Bactericidal Concentration (MBC) results between honey, lemon juice and honey/ lemon juice

Table 1: Average Minimum Inhibitory Concentration (MIC) ( $\mu \mathrm{g} /$ $\mathrm{ml}$ ) values for the test agents (Honey and Lemon juice) against Streptococcus pneumoniae.

\begin{tabular}{|c|c|c|}
\hline Bacterial isolates & Honey & Lemon \\
\hline $\begin{array}{c}\text { Streptococcus } \\
\text { pneumoniae }\end{array}$ & 37.1 & 31.0 \\
\hline
\end{tabular}

Table 2: Average Minimum Inhibitory Concentration (MIC) ( $\mu \mathrm{g} /$ $\mathrm{ml}$ ) values for the test agents (Honey/Lemon juice mixture) against Streptococcus pneumoniae.

\begin{tabular}{|c|c|c|c|c|c|}
\hline $\begin{array}{c}\text { Bacterial } \\
\text { isolates }\end{array}$ & $\mathbf{1 0 : 5 0}$ & $\mathbf{2 0 : 5 0}$ & $\mathbf{3 0 : 5 0}$ & $\mathbf{4 0 : 5 0}$ & $\mathbf{5 0 : 5 0}$ \\
\hline $\begin{array}{c}\text { Streptococcus } \\
\text { pyogenes }\end{array}$ & 32.9 & 27.9 & 25.8 & 22.5 & 18.8 \\
\hline
\end{tabular}

Table 3: Average Minimum Inhibitory Concentration (MIC) ( $\mu \mathrm{g} /$ $\mathrm{ml}$ ) values for the test agents (Lemon juice/Honey mixture) against Streptococcus pneumoniae.

\begin{tabular}{|c|c|c|c|c|c|}
\hline Bacterial isolates & \multicolumn{3}{|c|}{ Honey } & \multicolumn{3}{c|}{ Lemon } \\
\hline $\begin{array}{c}\text { Streptococcus } \\
\text { pyogenes }\end{array}$ & \multicolumn{3}{|c|}{43.3} & \multicolumn{2}{c|}{34.6} \\
\hline $\begin{array}{c}\text { Bacterial } \\
\text { isolates }\end{array}$ & $\mathbf{1 0 : 5 0}$ & $\mathbf{2 0 : 5 0}$ & $\mathbf{3 0 : 5 0}$ & $\mathbf{4 0 : 5 0}$ & $\mathbf{5 0 : 5 0}$ \\
\hline $\begin{array}{c}\text { Streptococcus } \\
\text { pneumoniae }\end{array}$ & 19.6 & 20.0 & 20.4 & 19.6 & 19.6 \\
\hline
\end{tabular}

Table 4: Average Minimum Inhibitory Concentration (MIC) ( $\mu \mathrm{g} /$ $\mathrm{ml}$ ) values for the test agents (Honey and Lemon juice) against Streptococcus pyogenes.

\begin{tabular}{|c|c|c|c|c|c|}
\hline $\begin{array}{c}\text { Bacterial } \\
\text { isolates }\end{array}$ & $\mathbf{1 0 : 5 0}$ & $\mathbf{2 0 : 5 0}$ & $\mathbf{3 0 : 5 0}$ & $\mathbf{4 0 : 5 0}$ & $\mathbf{5 0 : 5 0}$ \\
\hline $\begin{array}{c}\text { Streptococcus } \\
\text { pyogenes }\end{array}$ & 20.4 & 19.6 & 17.9 & 17.9 & 18.8 \\
\hline
\end{tabular}

Table 5: Mean zone of inhibition $(\mathrm{mm}) \pm$ SEM of the standard Antibiotic formulations against Streptococcus pneumonia.

\begin{tabular}{|c|c|c|c|c|c|}
\hline & CRO & LEV & AMC & AZM & CN \\
\hline $\begin{array}{c}\text { Streptococcus } \\
\text { pneumoniae }\end{array}$ & $21.7 \pm 1.92$ & $21.3 \pm 1.32$ & $19.3 \pm 2.07$ & $16.1 \pm 1.94$ & $20.4 \pm 1.56$ \\
\hline
\end{tabular}

\begin{tabular}{|c|c|c|c|c|c|}
\hline Bacterial isolates & $\mathbf{1 0 : 5 0}$ & $\mathbf{2 0 : 5 0}$ & $\mathbf{3 0 : 5 0}$ & $\mathbf{4 0 : 5 0}$ & $\mathbf{5 0 : 5 0}$ \\
\hline $\begin{array}{c}\text { Streptococcus } \\
\text { pneumoniae }\end{array}$ & 43.6 & 38.6 & 27.1 & 23.9 & 19.6 \\
\hline
\end{tabular}

Key: CRO: Ceftriaxone; LEV: Levofloxacin; AMC: Amoxicillin-Clavulanic acid; AZM: Azithromycin; CN: Gentamicin

Table 6: Mean zone of inhibition $(\mathrm{mm}) \pm$ SEM of the standard Antibiotic formulations against Streptococcus pyogenes.

\begin{tabular}{|c|c|c|c|c|c|}
\hline & CRO & LEV & AMC & AZM & CN \\
\hline $\begin{array}{c}\text { Streptococcus } \\
\text { pyogenes }\end{array}$ & $20.6 \pm 2.27$ & $19.5 \pm 1.80$ & $16.3 \pm 2.43$ & $15.6 \pm 1.42$ & $21.8 \pm 0.94$ \\
\hline
\end{tabular}

Key: CRO: Ceftriaxone; LEV: Levofloxacin; AMC: Amoxicillin-Clavulanic acid; AZM: Azithromycin; CN: Gentamicin

Generally, there's reduction in MIC (and MBC) in the mixture of Honey and Lemon juice compared to the Lemon juice alone of Honey and Lemon juice compared to the Honey alone (Table in some of the strains while increase in MIC (and MBC) were 1-6). There's also reduction in MIC (and MBC) in the mixture obtained in the other strains (Table 1-6)

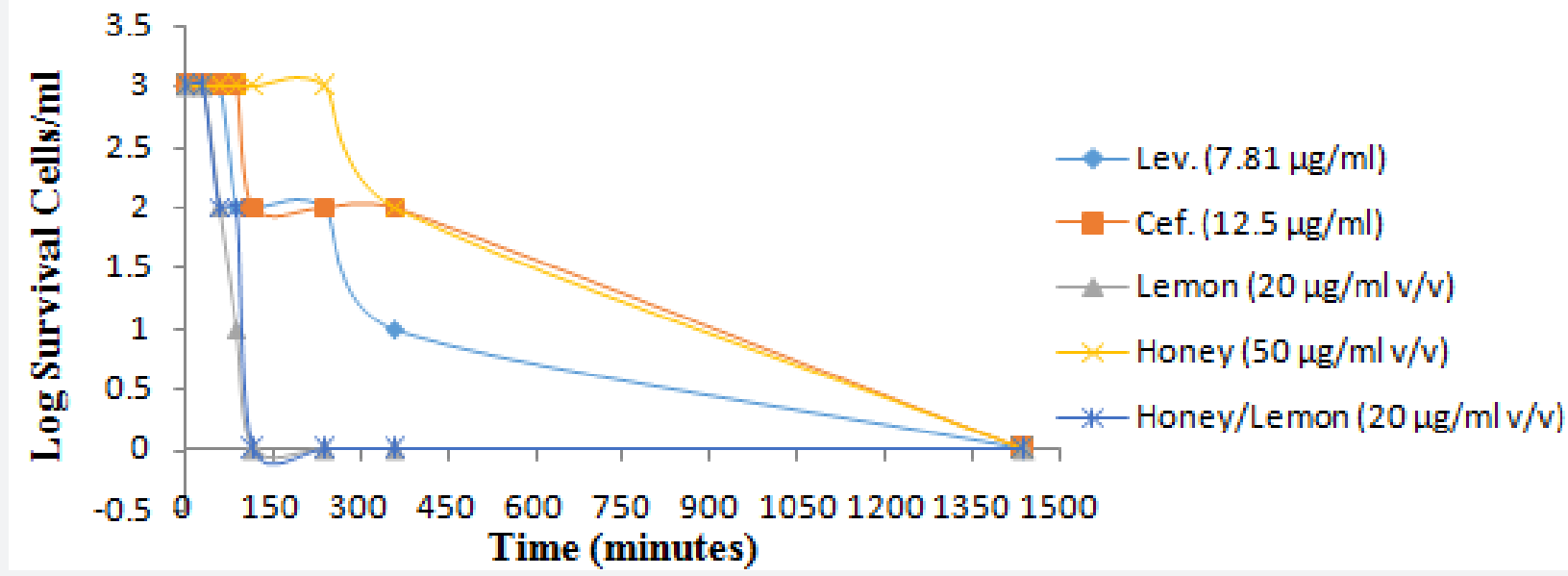

Figure 3: The Log of Survival cells/ml of Streptococcus pneumoniae (Sensitive) on exposure to standard antibiotics and honey, lemon and honey/lemon juice mixture. 


\section{Rate of kill}

Honey and Lemon juice mixture, Lemon juice effected complete killing at 120 minutes, as depicted by gradual decrease in the cell population from 30 minutes to 90 minutes and a steady decrease at 120minutes; while Ceftriaxone, Levofloxacin and Honey produced complete killing at 1440 minutes, as depicted by gradual decrease in cell populations from 30minutes to
360 minutes and a steady decrease to 1440 minutes for the susceptible Streptococcus pneumoniae (Figure 3).

Plate $2 \& 3$ below shows the susceptibility test plates of Streptocococcus pneumoniae with the largest zone of inhibition observed with honey/lemon juice mixture, undiluted lemon juice, Ceftriaxone and lowest zone shown by Azithromycin, Amoxicillin-Clavulanic acid and $50 \% \mathrm{v} / \mathrm{v}$ concentration of honey.

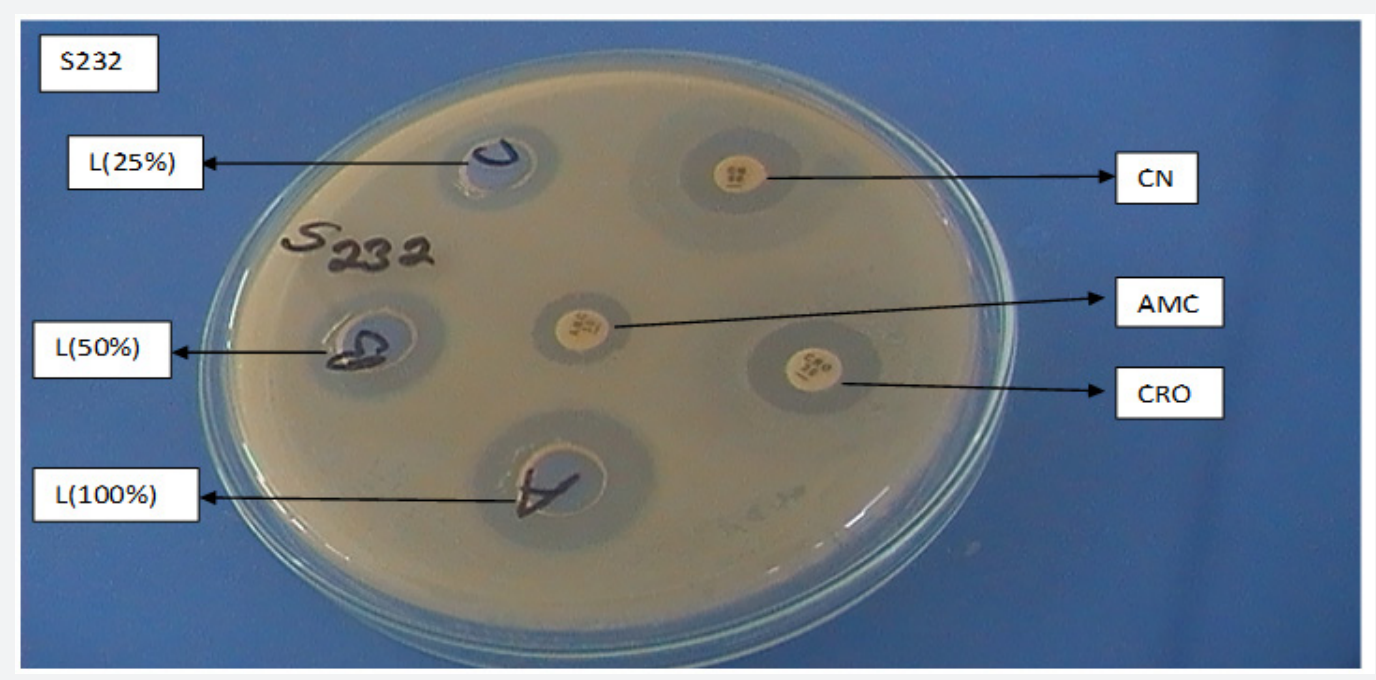

Plate II: Susceptibility Test plate of Streptococcus pneumoniae_1.

Key: L: Lemon juice; CN: Gentamicin; AMC: Amoxicillin-Clavulanic Acid and CRO: Ceftriaxone.

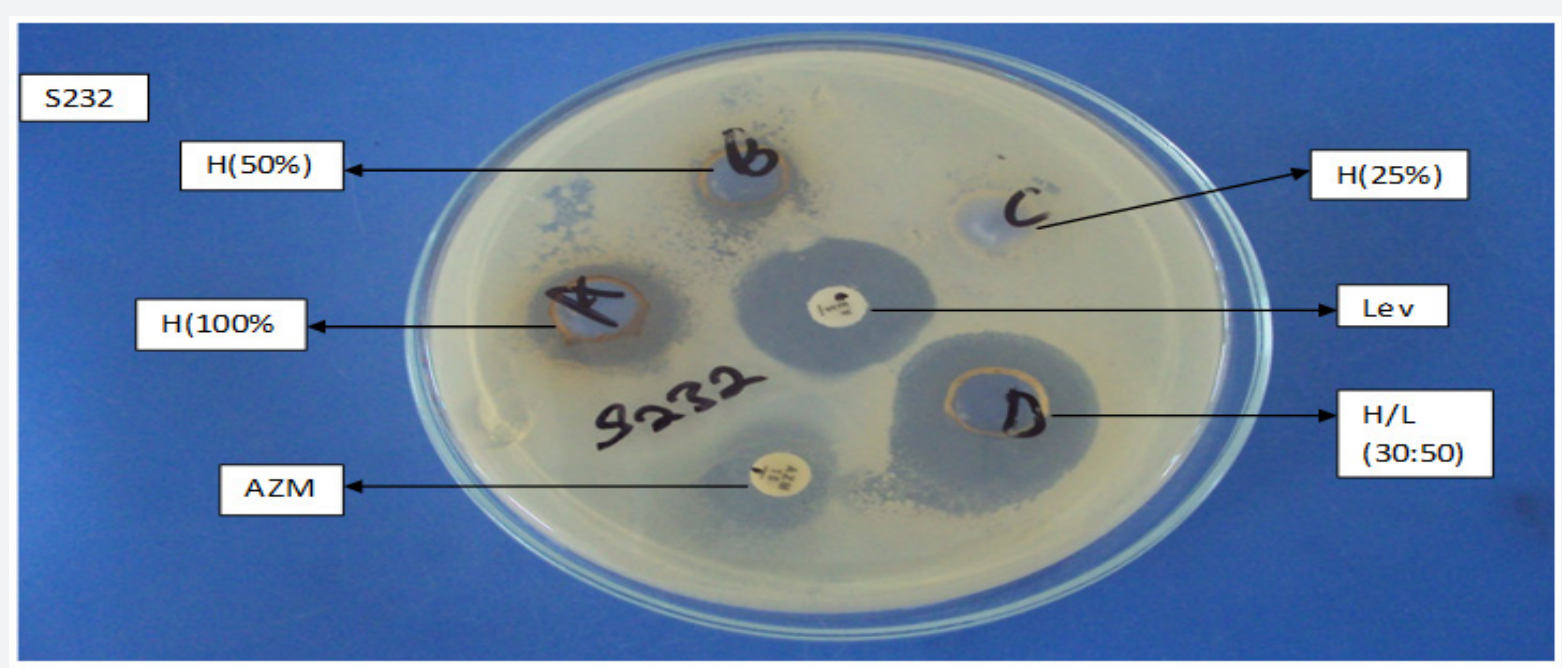

Plate III: Susceptibility Test plate of Streptococcus pneumoniae_2.

Key: H: Honey; Lev: Levofloxacin; AZM: Azithromycin; H/L: Honey and Lemon juice.

\section{Discussion}

All the tested bacterial isolates were completely susceptible to the crude concentrations of Honey, Lemon juice and the Honey/Lemon juice mixture. This activity is tight to the acidic nature of the honey and lemon juice, beside other antimicrobial properties they were known to possess. They were also moderately susceptible to Honey at $50 \% \mathrm{v} / \mathrm{v}$ concentration, Lemon juice at $25 \% \mathrm{v} / \mathrm{v}$ concentration; but showed resistance to
Honey at $25 \% \mathrm{v} / \mathrm{v}$ concentration. This is in agreement to works done by Ifra \& Ahmad [29] and Kawaii et al. [6] who reported that the stock solution of the honey samples inhibited the growth of all the bacterial isolates, but when the dilutions were made the efficacy reduced.

A better zone of inhibition was obtained with the honey/ lemon juice mixture, crude concentrations of the honey and that of the lemon juice compared to the reduced concentrations. 
This is in close proximity to the work of Hemal et al. [30], who reported that no significant result was found with $5 \%, 10 \%, 20 \%$ and $40 \%$ concentrations of honey solution. Zone of inhibition was observed with $60 \%$ concentration of honey solution, having $10.0 \mathrm{~mm}$ mean zone of inhibition. However, this is in contrast to a study by Faezeh et al. [31], who observed that concentrations below $37.5 \mathrm{ppm}$ were more efficient as antibacterials.

The minimum inhibitory concentrations which ranges from 20.0-75.0 (100\% Honey), 22.5-47.5 (100\% Lemon) and 17.525.0 (Honey/Lemon juice mixture) is in contrast to that of Faezeh et al. [31], who reported a minimum inhibitory concentrations for honey against Streptococcus mutans, Lactobacillus casei, L. rhamnosus and L. plantarum at 75, 75, 100 and 100ppm, respectively.

The rate of kill provides more accurate description of antimicrobial activity of antimicrobial agents than does the MIC [32]. The rate of kill of Streptococcus pneumonia on exposure to the test agents showed that Honey/Lemon juice mixture and Lemon juice effected a better killing (evidenced by the sharp decrease in the bacterial cell populations and complete killing effect in less than 24hours) than the Honey, which gave its complete killing at 24 hours. This is due to the highly acidic $\mathrm{pH}$ of the honey and lemon juice mixture. Kwakman et al. [33] also reported in their work that antibiotic susceptible and resistant isolates of S. aureus, S. epidermidis, Enterococcus faecium, E. coli, P. aeruginosa, E. cloacae, and Klebsiellaoxytoca were killed within $24 \mathrm{~h}$ by $10-40 \%(\mathrm{v} / \mathrm{v})$ honey.

Generally, inadequate antimicrobial treatment defined as ineffective treatment due to failure to complete prescribed dosage or prescription without carrying out the susceptibility testing, use of left-over drugs and self-medication by buying drugs from the illegal conduits is important factor in emergence of antibiotic resistant bacteria [34]. This has motivated many to traditionally use the honey and lemon which can be found in their environment and has been found effective. Therefore, honey and lemon juice mixture have better antibacterial activity than the honey or lemon juice when used alone.

\section{Conclusion}

Honey and lemon juice generally possess antibacterial activity against Streptococcus pneumoniae and Streptococcus pyogenes as obtained in this research. Honey and Lemon juice had more inhibitory effect against the tested bacterial isolates than the commonly used antibiotics especially Azithromycin and Amoxicillin-Clavulanic acid. Honey and Lemon juice can therefore be used as an alternative medicine in the treatment of respiratory tract infections.

\section{References}

1. Silveira FA, Melo GAR, Almeida EAB (2002) A High Grassland Bee Community in Southern Brazil: Survey and Annotated checklist (Insecta: Apidae). Journal of Kansas Entomological Society 85(4): 295308.
2. Molan P (1992) The Antibacterial Activity of Honey: 2. Variation in potency of the antibacterial activity. Bee World 73(2): 59-76.

3. Mandal S (2011) Honey: its medicinal property and antibacterial activity. Asian Pacific Journal of Tropical Biomedicine 1(2): 154-160.

4. Yoji Kato, Natsuki Umeda, Asuna Maeda, Daiki Matsumoto, Noritoshi Kitamoto, et al. (2012) Identification of a novel glycoside, leptosin, as a chemical marker of manuka honey. J Agric Food Chem 60(13): 34183423.

5. NPCS (2012) Handbook on Agro Based Industries ( $2^{\text {nd }}$ edn), Amazon. Published by Niir Project Consultancy Services, India, pp. 75-78.

6. Satoru Kawaii, Yasuhiko Tomono, Eriko Katase, Kazunori Ogawa, Masamichi Yano, et al. (2000) Quantitative study of flavonoids in leaves of Citrus plants. J Agric Food Chem 48(9): 3865-3871.

7. Sara Burt (2004) Essential oils: Their antibacterial properties and potential applications in foods: A review. International Journal of Food Microbiology 94(1): 223-253.

8. Jeremy PTW, Jane W, Charles MW (2006) The respiratory system at a glance. Published by Wiley-Blackwell, USA, pp. 11-16.

9. Sabyasachi S (2008) Principles of Medical Physiology. Thieme. CBS Publishers and Distributors, Delhi, India, p. 309.

10. Venkat T (2013) Bronchial Anatomy.

11. Eccles MP, Grimshaw J, Walker A, Johnston M, Pitts N (2007) Applying Psychological Theories to Evidence-based Clinical Practice: Identifying factors predictive of managing upper respiratory tract infections without antibiotics. Implement Sci 2: 26.

12. Duckworth D (2006) Streptococcus pyogenes.

13. (2005) National Institute of Allergy and Infectious Diseases. Group A Streptococcal Infections.

14. Tortora G, Funke B, Case C (2007) Microbiology: An Introduction, $9^{\text {th }}$ (edn), Pearson Education Inc, UK.

15. Aziz RK, Rita K, Bruce AJ, William LT, Sarah LR, et al. (2010) Microevolution of Group A Streptococci In-Vivo: Capturing Regulatory Networks Engaged in Sociomicrobiology, Niche Adaptation, and Hypervirulence. PLoS ONE 5(4): 9798.

16. Jim Dwyer (2012) An Infection, Unnoticed, Turns Unstoppable. The New York Times.

17. Sharma S (2006) Streptococcus: Group A Infections.

18. Ryan KJ, Ray CG (2004) Sherris Medical Microbiology $4^{\text {th }}$ (edn), McGraw Hill, USA, pp. 396-401.

19. Reed AC Siemieniuk, Dan B Gregson, M John Gill (2011) The persisting burden of invasive pneumococcal disease in HIV patients: an observational cohort study. BioMed Central Infectious Diseases 11: 314.

20. Ron Dagan (2000) Treatment of acute otitis media-challenges in the era of antibiotic resistance. Vaccine 19(1): 9-16.

21. Cheesebrough (2010) Medical Laboratory Manual for Tropical Countries. Microbiology: Cambridge University Press, UK, pp. 137-188.

22. Adeniyi BA, Odelola HA, Oso BA (1996) Antimicrobial Potential of Diospyrosmesphiliformis (Ebenaceae). African Journal of Medical Science 25(3): 221-224.

23. Adeshina GO, Noma ST, Onaolapo JA, Ehinmidu JO (2010) Preliminary in-vitro antibacterial activities of ethanol and aqueous extracts of Rauvolfiacaffra. International Journal of Pharmaceutical Research and Development 2(8): 1-8.

24. Samie A, Obi CL, Bessong PO, Namrita L (2005) Activity profiles of fourteen selected medicinal plants from venda communities in South 
Africa against fifteen Clinical Bacterial species. African Journal of Biotechnology 4(12): 1443-1451.

25. Clinical and Laboratory Standards Institute (2008) Performance Standard for Antimicrobial Susceptibility Testing; Eighteenth Informational Supplemen 28(1): 80-160.

26. Akinyemi KO, Oladapo O, Okwara CE, Ibe CC, Fasure KA (2005) Screening of crude extracts of six medicinal plants used in SouthWest Nigerian unorthodox medicine for anti-methicillin resistant Staphylococcus aureusactivity. BMC Complement Altern Med 5: 6.

27. Aboaba 00, Smith SI, Olude FO (2006) Antibacterial Effect of Edible plant on Escherichia Coli 0157:H7. Pakistan Journal of Nutrition 5(4): 325-327.

28. Aldona L Baltch, Raymond P Smith, William J Ritz, Lawrence H Bopp (1998) Comparison of inhibitory and bactericidal activities and post antibiotic effect of Ly 333328 and Ampicillin used singly and in combination against Vancomycin Resistant Enterococcus faecium. Antimicrobial agents and chemotherapy 42(10): 2564-2568.

29. Ifra G, Sheikh SA (2009) Antibacterial Activities of Honey, Sandal oil and Black pepper. Department of Environmental Sciences, Fatima Jinnah Women University, Rawalpindi, Pakistan. Pakistan Journal of Botany 41(1): 461-466.

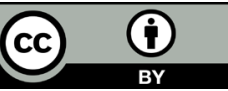

This work is licensed under Creative Commons Attribution 4.0 Licens DOI: 10.19080/AIBM.2017.04.555660
30. Hemal RP, Ajith Krisnan CG, Thanveer K (2013) Antimicrobial effect of honey on Streptococcus mutans-An in vitro study. International Journal of Dental Science and Research 1(2): 46-49.

31. Faezeh K, Zahra G, Marzieh T, Azadeh A, Mohsen DM, et al. (2014) Antibacterial activity of milk vetch flower honey against four bacteria of human oral: Streptococcus mutans, Lactobacillus casei, Lactobacillus rhamnosus and Lactobacillus plantarus. Annual Research \& Review in Biology 4(22): 16-30.

32. Mandal S, Pal NK, Chowdhury IH, Deb Mandal M (2009) Antibacterial activity of ciprofloxacin and trimethoprim, alone and in combination, against Vibrio cholerae 01 biotype El Tor serotype Ogawa isolates. Pol J Microbiol 58(1): 57-60.

33. Kwakman PH, Van den Akker JP, Güçlü A, Aslami H, Binnekade JM (2008) Medical-grade honey kills antibiotic cresistant bacteria in vitro and eradicates skin colonization. Clin Infect Dis 46 (11): 1677-16682.

34. Kollef $\mathrm{MH}$ (2000) Inadequate antimicrobial treatment and an important determinant outcome for hospitalized patients. Clin Infect Dis 31(4): 5131-5138.

\section{Your next submission with Juniper Publishers will reach you the below assets}

- Quality Editorial service

- Swift Peer Review

- Reprints availability

- E-prints Service

- Manuscript Podcast for convenient understanding

- Global attainment for your research

- Manuscript accessibility in different formats

( Pdf, E-pub, Full Text, Audio)

- Unceasing customer service

Track the below URL for one-step submission https://juniperpublishers.com/online-submission.php 